\title{
The Protection of Indigenous Peoples' Seed Rights during Ethnobotanical Research
}

\author{
Letitia M. McCune ${ }^{1 *}$ \\ ${ }^{1}$ BotanyDoc LLC, Tucson, AZ, USA. \\ *letitiamccune@gmail.com
}

\begin{abstract}
Recognition of the importance of biodiversity for global food security and the community food sustainability movement has helped increase awareness of seed rights. International treaties created to ensure the world's access to seed biodiversity address access to seed banks for breeding purposes. Ethnobotanists are often required to deposit research plant specimens with government seed banks or herbariums. If Indigenous Peoples' plants are then used developing patented varieties, are their rights recognized? These rights depend upon recognition of Indigenous Peoples as plant breeders, prior informed consent (PIC) protocols, access and benefit sharing (ABS) agreements via material transfer agreements, and benefits returned to Indigenous and local communities per the Nagoya Protocol. To ensure such rights to genetic material and associated intellectual property rights, documentation of these agreements and links to the people and communities from which they originated needs to occur at first collection and throughout subsequent research, conservation, and breeding programs.
\end{abstract}

Received August 6, 2017

OPENひACCESS

Accepted April 11, 2018

DOI 10.14237/ebl.9.1.2018.1076

Keywords Farmers rights, Intellectual property rights, Seeds, Sovereignty, Patents, Indigenous Peoples

Copyright (c) 2018 by the author(s); licensee Society of Ethnobiology. This is an open-access article distributed under the terms of the Creative Commons Attribution-NonCommercial 4.0 International Public License (https://creativecommons.org/licenses/by-nc/4.0), which permits non-commercial use, distribution, and reproduction in any medium, provided the original author and source are credited.

\section{Introduction}

In the debate over patenting of seeds and availability of the world's seed germplasm for research and community gardening, insufficient attention is given to intellectual property rights of local and Indigenous communities that develop plant varieties over generations. This situation is gradually improving with recognition of these rights in international agreements and transfer agreements between the worlds' large seed banks. Ethnobiologists can play an essential role in promoting these efforts through rigorous documentation during all phases of research. Nevertheless, the question remains, can these Peoples' rights be protected through the multiple stages of distribution and use in the name of promoting biodiversity?

Advocates of biodiversity and climate change preparation seek seeds as genetic resources representing the world's biodiversity. As in the past, they are often housed in national and international seed banks without specifying what will be done with them via access and benefit sharing agreements with the farmers, gardeners, and cultivators from whom they were collected. This scenario contrasts with patent rights enjoyed by commercial seed companies and plant breeders, which specify who can buy, sell, distribute, and use seeds and genetic resources. These mechanisms permit patent holders to limit use of seeds and plants used in developing their products if they are sufficiently similar. It is likely commercial seed companies and breeders would be concerned with measures protecting local and Indigenous Peoples' seed rights if they were to result in reduced access to genetic resources for developing new varieties. Such considerations continue to increase the chances of exploitation (Posey 2005) as genetic resources and traditional agricultural knowledge are transferred to developed nations and biotechnology centers (Brush 2005).

Traditional and Indigenous farmers have seed rights concerns (for example, La Via Campasina 2012) that include the ongoing ability to grow out their seeds each year as well as the right to enter into access and benefit sharing agreements even if their seeds or 
other genetic resources are used by commercial entities to patent new varieties. For these purposes, local and Indigenous farmers should be considered plant breeders on equal standing to commercial seed companies, since they have developed their plants over generations for resilience under particular environment conditions, including climatic fluctuations such as drought, as well as specific local diseases and insect pests. These are the kinds of characteristics plant scientists are interested in accessing and incorporating into their own (limited access) seeds through breeding or biotechnology programs.

Laws in many countries allowing plant breeders and seed companies to decide who can distribute and use their seeds, largely stem from The International Union for the Protection of New Varieties of Plants, plant variety protections, and subsequently the U.S. Patent System (see Elvin-Lewis 2006; Gepts 2004). Interest in seed biodiversity among grassroots organizations and home gardeners has led to seed swaps and libraries running up against seed laws designed to protect plant breeders. Who protects traditional farmers' and breeders' rights? If their seeds are freely distributed at these venues and thereby obtained by commercial seed breeders, their rights to enter into access and benefit sharing agreements could be lost. What can be done in these instances to protect local Peoples' intellectual property rights while also promoting biodiversity? This paper focuses on this issue, especially with regard to commercial seeds developed without innovation and new varieties developed from traditional ones.

\section{International agreements}

Two of the key international agreements addressing seed rights are The International Treaty on Plant Genetic Resources for Food and Agriculture (also known as the Seed Treaty) and the Nagoya Protocol. The Seed Treaty was developed by the United Nations Food and Agricultural Organization (FAO 2001). This accord put 64 major food and feed crops into the public domain under government control, usually in national seed banks. In this context, public domain availability signifies access from the holding country conditioned upon certain standard agreements. If a plant breeder or seed company from one country desires access to the wheat or rice varieties, for example, of another Seed Treaty signatory country, they must contact that country's seed bank and fill out their Standard Material Transfer
Agreement. This is a legal document that includes a Multilateral System of Compensation (MLS). In the MLS, if one develops a commercial product from the country's seeds (for example, a patent or certificate), a percentage of the profit (usually $0.5 \%$ ) must be returned to the MLS international pool, which distributes these monies to selected conservation and agricultural programs that do not necessarily benefit the seeds' originators.

The Nagoya Protocol is an offshoot of the Convention on Biological Diversity agreement (Convention on Biological Diversity 2010), elaborated in 2010 and taking effect in 2014-2015. This agreement specifically focuses on Indigenous and local communities (termed ILCs) and the importance of prior informed consent (PIC) and access and benefit sharing agreements (ABS), especially as they relate to genetic resources, including those from plants. These agreements and the use of the associated genetic resources in all forms of research going forward are monitored by national and international ABS clearing houses along with any patents that result from these agreements.

The large international farmers' rights organization La Via Campesina is comprised of 182 farmer organizations, representing over 200 million farmers in 81 countries. This organization has formally spoken out against the Seed Treaty and its Multilateral System of Compensation for lacking benefits for its members (La Via Campesina 2011). La Via Campesina has characterized this system as promoting theft of their seeds, considering it grants them no rights to determine how their seeds are used and no access to their materials held in the seed banks. This large organization defends the benefits of its members' peasant seed systems over those they see as controlled by seed corporations. More recent statements from La Via Campesina have suggested it is more hopeful about the Nagoya Protocol, although skeptical that the ABS clearing houses will have adequate power to monitor and enforce agreements (La Via Campesina 2016). As the Nagoya Protocol makes headway in signatory countries, additional challenges arise in reconciling jurisdictions and regulations to ensure and monitor compliance without undue burden or complication. In some countries, the Multilateral System of Compensation remains in effect, utilizing narrow protection categories based in the dominant cultures' notions of resources, 
knowledge, and justice (Halewood et al. 2013; Oguamanam 2011).

\section{The Patent System}

Whereas many countries in the international community are signing and ratifying the Nagoya Protocol and its focus on ABS systems, the United States is not a party to the convention. In the US, seed rights are derived through the patent system. While a true patent is now reserved for cases of unique production (often using biotechnology), two other forms of protections are afforded to plant breeders. These include United States Department of Agriculture (USDA) Plant Variety Certificates and Utility Patents, which limit the use of seeds by allowing plant breeders and seed companies to determine who can sell, buy, distribute, and use their genetic resources (Elvin-Lewis 2006; Gepts 2004). Unfortunately, small local farmers and breeders rarely employ these protections because their cost can be prohibitive. They also require protected plants to produce uniform and stable lines while local community farmers often have biodiverse landraces whose genetic variability impart resilience to environmental changes. Unfortunately, the United States system recognizes and protects monocultures rather than biodiverse crop lines.

Inherent to the patent system are some protections, including the USDA examiners' database and the application form "disclosure of the origin of genetic resources" (Elvin-Lewis 2006). The database is a compilation of notes and publications that describe prior art, which in patent law is any information or knowledge of items similar to that being patented, especially that which is publicly available before the patent request. These include descriptions of seeds previously created and used by Peoples of the world, which theoretically precludes their being patented by someone else. Patent application forms also solicit disclosure of the origin of genetic resources, including how a new variety was created. Answers to the questions in this section could permit the examiner to determine if new or novel seeds are substantially different from those that were used to create them. In addition, they could help the examiner determine if plants used in seed development have access and benefit agreements associated with them that might restrict their use or require return of benefits. Unfortunately, this section does not appear to be mandatory.
The classic example of the Enola bean Plant Variety Certificate illustrates the importance of these patent application disclosures (Dutfield 2003; Garcia 2007). This certificate was obtained by a bean breeder from Colorado after buying a bag of beans (Phaseolus vulgaris) from a vendor in Mexico and conducting minor crosses to stabilize the yellow color of one of the beans from the bag. He then applied for certification of the yellow bean, which he called "Enola." However, the yellow beans in the bag he purchased are a staple food in Mexico. As a result of the certificate, Mexican farmers suddenly faced royalty fee charges when they tried to export their yellow beans to the United States, as they had been doing for many years. In addition, established United States growers and distributers of the yellow beans faced lawsuits. Despite abundant evidence that the patent/ certificate application should have been revoked, doing so took almost 10 years. In the meantime, Mexican farmers lost revenue.

As compared to agricultural seeds, Indigenous Peoples' medicinal plants have faced an even longer history of misuse, eventual recognition of rights, and creation of mechanisms to protect those rights. Some classic examples of biopiracy of medicinal plants include patenting of traditional Indigenous uses of neem (Azadiracbta indica) and turmeric (Curcuma longa) from India (Dutfield 1999; Garcia 2007). Subsequently, India began documenting and registering national traditional plant uses and varieties in order to have evidence of prior art to fight such patents. As the world increasingly recognizes the benefits of Indigenous Peoples' and local farmers' plants for their potential drought, disease, and pest resistance, these genetic resources are at greater risk of biopiracy. The agreements used for potential pharmaceutical products derived from Indigenous Peoples' medicinal plants and associated intellectual property deserve to be similarly used for the genetic resources potentially used for developing new patentable varieties of agricultural plants.

\section{Upon Collection}

Through my experience researching the Native Seeds/ SEARCH seed bank collection for potential future accessions, subsequent work on their board focusing on intellectual property and farmers' rights issues, and as ethics chair for The Society for Economic Botany, it became apparent to me that the issues discussed here-recognition of the rights to seeds and associated traditional knowledge-can be 
strengthened through rigorous documentation at the time seeds and/or plants are first collected. Community protocols can be addressed by any number of methods (Bannister 2008) and research agreements (Cuerrier et al. 2012; Fediuk and Kuhnlein 2003; Scott and Receveur 1995). Records of agreements regarding ongoing rights to collected plant material should be documented and must accompany seed and plant specimen transfers, along with other formal research agreements with local communities and countries. Ideally, the individual(s) providing seed or plant specimens should be identified and it should be documented if these materials were grown on tribal lands and if local community leaders were aware of the acquisition. Agreements should be attached to the collection sheet along with documentation of any restrictions to associated traditional knowledge. In addition, it is important that documentation be placed in seed banks, herbariums, or other publicly accessible repositories regarding understandings of the provider's plans for the specimens, including how they will be stored, transferred, or distributed.

Some of the objectives detailed above may be accomplished by adding supplementary information on the back side of a typical collection sheet describing the seed/plant, the collection location, and how it was grown. This additional information could include the identity of the individual or community that provided the material and indicate whether any agreements are in place regarding uses, restrictions, or intended distribution. Figure 1 presents an example of how some of this information could be recorded and accompany more formal agreements (Native Seeds/ SEARCH 2015a; CETAF 2015). The donor or provider could list restrictions on this form, such as sacred properties and requirements that the Indigenous or local name must be retained or that seeds may only be grown on tribal soil. It is also possible that donor's or provider's cultural representatives may stipulate no restrictions other than free access to seeds, which also must be well documented to avoid future misunderstandings. The provider and collector should sign the collection sheet with copies of this sheet retained by both collector and provider.

Upon deposit in a seed bank or herbarium, copies of collection notes should be held in a permanent archive to preserve access to all agreements, restrictions, and links to the tribal entity. When a collection is included in catalogues, permanent links to the originators of the plants or seeds and any associated agreements must be provided. These methods insure researchers and the USDA examiner's office have easy access to all of the information necessary to avoid improper patenting or certification by third parties of plants and seeds as though they were new varieties that can be restricted in this manner.

When plant specimens are placed in an herbarium, methods are needed to continually link them back to the donor or provider and original breeders. Even after the collection sheet is deposited, annotation labels can be placed on the specimen sheet with links to other notes, documents, or agreements (Hodgson 2002). Ethnobotanical information can also be included on the herbarium sheet (Bye 1986). These steps are of increasing importance considering the Nagoya Protocol's requirement of ongoing documentation of all uses of genetic resources after acquisition and the possibility of extracting DNA from herbarium specimens using contemporary technologies.

\section{Seed Bank Protections}

What can seed banks do to protect farmers' and cultivators' seed rights? My familiarity with this topic derives from training in plant science and working at a biotechnology company that was subsequently acquired by Monsanto. This question is particularly relevant when seeds housed in a seed bank are transferred to other institutions from which they might be removed and used. Most large national and international seed banks use the Standard Material Transfer Agreement (SMTA) mandated for use by parties in signatory countries of the Seed Treaty. This is a legally binding agreement that stipulates how transferred seeds are to be used and often includes the MLS of compensation of benefits.

Other ways of restricting access to seeds in a seed bank include so-called "black boxes." Theoretically, only the donor or provider of a "black box" deposit held in a seed bank can access the seeds within such a box. However, as illustrated by the Svalbard's Doomsday Vault/Global Seed Bank and USDA seed bank, the contracting parties may be required to sign an agreement stipulating that these same seeds are freely available for research. Not all seed banks require this exemption to black box restrictions. For example, the Missouri Botanical Garden's material transfer agreement (MTA) states (Missouri Botanical Garden 2010: paragraph 1): 
Collection Name/Number Collection Date

Was this plant material purchased from a market or vendor? $\quad$ Yes (Price ___ $\square$ No Was this plant material collected or grown on land associated with an Indigenous/local community?
$\square$ Yes (Community name:
) $\square$ No
$\square$ Unknown

Is this plant material part of the cultural heritage of an Indigenous/local community? $\square$ Yes $\square$ No $\square$ Unknown

If associated with a community in either question above, have the community leader(s) been contacted and agree to this collection?
$\square$ Yes
$\square$ No
$\square \mathrm{N} / \mathrm{A}$

If yes, explain:
Are there permits or agreements associated with this collection?
$\square$ Yes
$\square$ No
If yes, list and attach (include Prior Informed Consent, Access and Benefit Sharing, Material Transfer, etc.):

It is agreed the plant material and associated information collected can be distributed to (check or cross out all that apply):
$\square$ gardeners and farmers
$\square$ researchers that are not breeders
$\square$ plant breeders
$\square$ seed companies
$\square$ national seed banks
$\square$ national herbariums
$\square$ university herbariums
$\square$ other

Are there limits on how this plant material and associated information is to be used? $\quad \square$ Yes $\quad \square$ No If yes, list:

$\begin{aligned} & \text { The donor and recipient agree to the above and that subsequent transfer of this plant material will contain these same } \\ & \text { agreements on use with records of material transfer being kept. }\end{aligned}$
Donor/Provider
Address
Phone/email__filiation__

Figure 1 An example of information that could be included on the back side of collection sheets. 
Samples will not be made available for bioprospecting endeavors, screening for genes of interest in agricultural or applied research, or any other potential commercial application.

In addition, many seed banks do not distribute seeds to individuals. This restriction became an issue for La Via Campasina, which wanted their represented farmers to have ongoing access to their deposited seeds (La Via Campesina 2012). Nevertheless, this blanket restriction may serve as a protection against individual representatives of seed companies gaining access to seeds that otherwise would require formal written agreements with a breeding company. The USDA also has a so-called "Restricted Use Materials" list that presumably influences what type of MTA is used (if any).

Even small seed banks can continue to promote the protection of seed rights by rigorously documenting where seeds are sent (including such inhouse programs as Native Seeds/SEARCH's free seed program for Native Americans). The creation of permanent transfer and distribution records databases could decrease potential confusion arising when, for example, Hopi seeds from the southwestern United States are found growing on Seminole lands in Florida. Such records provide traceable links that may be availed if seeds fall in the hands of breeders seeking plant variety certificates as well as to assist researchers studying the origins of particular agricultural varieties.

Small seed banks should also have policies in place for handling requests from plant breeders and corporate seed companies. These policies could include such resources as a standard rejection letter and an MTA specifying how seeds are to be used. Many seed banks utilize the SMTA, but MTAs may also vary substantially. A non-standard approach is exemplified by Native Seeds/SEARCH's innovative printing of a mini-MTA on their seed packets and mailings, including the following statement (Native Seeds/SEARCH 2015: paragraph 4):

Acceptance of these seeds is an agreement that these seeds will not be used for commercial breeding with a patent outcome unless there are written agreements with the originators of the seeds in NS/S's collection.

This approach is similar to the Open Source Seed Initiative's subsequent placement of a pledge on their seed packets. This statement restricts patents and promotes acknowledgement of source material (Kloppenburg 2014: paragraph 4):

...By opening this packet, you pledge that you will not restrict others' use of these seeds and their derivatives by patents, licenses, or any other means. You pledge that if you transfer these seeds or their derivatives you will acknowledge the source of these seeds and accompany your transfer with this pledge.

The language "breeding with a patent outcome" and "or their derivatives" is instrumental for recognizing that plants' many genetic forms may be used for restrictive purposes. Open Source Seeds, a German nonprofit organization, has used similar language in a legal license to use its seeds (Kotschi and Rapf 2016). The license requires that any future use or modification of their seeds, whether for profit or not, must remain open access. This organization intends for its line of open access seeds to be an alternative to privatized seeds, such as those restricted by patents and plant variety protection certificates.

While open source statements and licenses help mitigate against the privatization of seeds and promote farmers' rights to use them, they do not address benefit sharing. Plant breeders may easily obtain seeds for the purposes of creating and commercializing products, but additional measures are required to ensure that their originators share in the derived benefits. For example, if hybrids are developed from seeds with drought, disease, pest resistance, the families or communities that originally developed them over generations should be recognized and formally included in agreements. Statements on seed packets, use licenses, and MTA should be included with seed packets traded at seed swaps and distributed through seed libraries, especially if there exists any chance the seeds originated from Indigenous Peoples or other communities that may have, or desire to have, ABS agreements.

\section{Seeds are Valuable}

Seeds and plants developed over generations by Indigenous Peoples and local communities around the world have unique properties acquired through stewardship and traditional breeding strategies and associated with the lands and cultures where they originated. These properties may include genetic resources to resist drought, water logging, salt, and pests. They may also have desirable flavor, nutritional, and medicinal properties. As the heritage food revival 
increases the diversity of food supplies in some regions and countries, awareness is increased regarding food and seed sovereignty, as well as the dangers of improper patenting of Indigenous Peoples' heritage foods and crops (Nabhan 2016). Ethnobotanists can help protect farmers' and Indigenous communities' rights to their own unique plant varieties. In fact, it has been argued that the survival of ethnobiology and anthropology depends on recognizing and compensating this type of traditional knowledge (Posey 1990). Ethnobiologists' role in conservation includes thorough documentation and archiving of biodiversity and associated traditional knowledge, along with honoring the rights of Indigenous Peoples, as set forth in the United Nations Declaration on the Rights of Indigenous Peoples (Wilder et al. 2016). It is precisely this type of documentation that can assure appropriate repatriation of seeds to communities who need or desire access to their traditional plant resources (Nazarea 2013).

Although seed saving activities and seed libraries continue to multiply in the United States and help promote awareness of locally adapted seeds (Campbell and Veteto 2015), greater recognition is also needed of seeds' origins and their potential exploitation by commercial interests. The seed packet statements and licenses mentioned in this article illustrate the kinds of methods that can be used to increase awareness and help prevent exploitation of Indigenous Peoples' agricultural knowledge and resources. Considering that seed banks often lack documentation and characterization of their collections derived from traditional Peoples (Brush 2005), important steps to reinforce these Peoples' rights include documenting understandings and agreements made when specimens were first collected and including them with deposits to seed banks and herbariums.

When ethnobiologists publish, they should include documentation of seed and plant collection histories and links to associated agreements, thereby increasing the chances they are included in the USDA Plant Variety Protection Office database. These are the kinds of information needed to prevent patenting of Indigenous and local farmer's seeds and facilitate overturning of inappropriate restrictive plant certificates. Additionally, ethnobotanists may be called upon to identify plants or seeds and serve as expert witnesses when potential misuse occurs.
Irrespective of whether seed collectors, ethnobotanists, and originators and donors of seeds agree with the kinds of patents discussed in this article, or whether or not the individuals providing specimens prefer to remain anonymous (Swiderska et al. 2009), documentation should be in place that establishes links to any ILCs or use agreements, even those that allow unrestricted biotechnology access. Lack of accessible documentation may lead to uncertainty about whether agreements were honored or biopiracy intentionally was committed by the collector that resulted in a loss of seed rights. Seed sovereignty rights are improving, and so shall control of these traditional resources through local seed banks and legal mechanisms, as exemplified by international recognition of the Nagoya Protocol. Through their ability to reinforce these rights via improved documentation, as described above, ethnobiologists can effectively advocate for Indigenous Peoples and their seed rights ${ }^{1}$.

\section{Notes}

${ }^{1}$ For more information on seed rights, the author suggests reading works by G. Dutfield, D. A. Posey, S. A. Laird, C. Fowler, P. R. Mooney, and G. P. Nabhan, among others. Regarding other methods of intellectual property protection for Indigenous Peoples, see Drahos and Frankel (2012) and Swiderska et al. (2009).

\section{Declarations}

Permissions: None declared.

Sources of funding: None declared.

Conflicts of Interest: None declared.

\section{References Cited}

Bannister, K. 2008. Non-Legal Instruments for the Protection of Intangible Cultural Heritage: Key

Roles for Ethical Codes and Community Protocols. In Protection of First Nations Cultural Heritage: Laws, Policy, and Reform, edited by C. Bell and R. K. Paterson, pp. 278-308. UBC

Press, Vancouver, Canada.

Brush, S. B. 2005. Protecting Traditional Agricultural Knowledge. W ashington University Journal of Law and Policy 17:59-109.

Bye, R. 1986. Voucher Specimens in Ethnobiological Studies and Publications. Journal of Ethnobiology 6:18 . 
Campbell, B. C., and J. R. Veteto. 2015. Free Seeds and Food Sovereignty: Anthropology and Grassroots Agrobiodiversity Conservation Strategies in the US South. Journal of Political Ecology 22:357-465.

CETAF. 2015. Standard Material Transfer Agreement (MTA1) for Provision of Material with No Change in Ownership. Available at: nagoyaprotocol.myspecies.info/node/3. Accessed on July 2, 2018.

Convention on Biological Diversity. 2010. The Nagoya Protocol on Access to Genetic Resources and the Fair and Equitable Sharing of Benefits Arising from their Utilization (ABS) to the Convention on Biological Diversity [web page]. Available at: https://www.cbd.int/abs/about/ default.shtml/. Accessed on May 31, 2017.

Cuerrier, A., A. Downing, E. Patterson, and P. S. Haddad. 2012. Aboriginal Antidiabetic Plant Project with the James Bay Cree of Québec: An Insightful Collaboration. Journal of Enterprising Communities: People and Places in the Global Economy 6:251-270.

Drahos P., and S. Frankel. 2012. Indigenous People's Innovation: Intellectual Property Pathways to Development. The Australian National University Press, Canberra, Australia.

Dutfield, G. 1999. Intellectual Property Rights, Trade and Biodiversity: The Case of Seeds and Plant Varieties. IUCN Project on the Convention on Biological Diversity and the International Trade Regime. IUCN, Gland, Switzerland. Available at: http://www.sristi.org/material/mdpipr2003/ MDPIPR2003CD/M5\%20Intellectual\% 20property $\% 20$ rights.pdf. Accessed on May 31, 2017.

Dutfield, G. 2003. Protecting Traditional Knowledge and Folklore: A Review of Progress in Diplomacy and Policy Formulation. Intellectual Property Law: Articles on Cultural Expressions and Indigenous Knowledge. Intellectual Property Rights 4. Available at: http://www.iprsonline.org/resources/docs/ Dutfield $\% 20-\% 20$ Protecting $\% 20$ TK $\% 20$ and $\%$ 20Folklore\%20-\%20Blue\%201.pdf. Accessed on January 9, 2018.

Elvin-Lewis, M. 2006. Evolving Concepts Related to Achieving Benefit Sharing for Custodians of Traditional Knowledge. Ethnobotany Research and Applications 4:75-96. DOI:10.17348/era.4.0.75-96.
FAO. 2001. International Treaty on Plant Genetic Resources for Food and Agriculture [web page]. Available at: http://www.fao.org/plant-treaty/overview/en/. Accessed on May 31, 2017.

Fediuk, K., and H. V. Kuhnlein. 2003. Indigenous Peoples and Participatory Health Research [web page]. World Health Organization, Geneva, Switzerland. Available at: http://www.who.int/ethics/ indigenous_peoples/en/index14.html. Accessed on May 31, 2017.

Garcia, J. 2007. Fighting Biopiracy: The Legislative Protection of Traditional Knowledge. Berkeley La Raz̧a Law Journal 18. DOI:10.15779/Z38M378.

Gepts, P. 2004. Who Owns Biodiversity, and How Should the Owners Be Compensated? Plant Physiology 134:1295-1307. DOI:10.1104/ pp.103.038885.

Halewood, M., E. Andrieux, L. Crisson, and J. R. Gapusi, J. Wasswa Mulumba, E. Kouablan Koffi, T. Yangzome Dorji, M. Raj Bhatta, and D. Balma. 2013. Implementing 'Mutually Supportive' Access and Benefit Sharing Mechanisms Under the Plant Treaty, Convention on Biological Diversity, and Nagoya Protocol. Law, Environment and Development Journal 9:68-96.

Hodgson, W. C. 2002. Voucher Specimens and Their Importance to Ethnobotanical Studies. Unpublished manuscript, Desert Botanical Garden Herbarium, Phoenix, AZ.

Kloppenburg, J. 2014. The Unexpected Outcome of the Open Source Seed Initiative's Licensing Debate [web page]. Available at: https:// opensource.com/law/14/5/legal-issues-opensource-seed-initiative. Accessed on May 31, 2017.

Kotschi, J., and K. Rapf. 2016. Liberating Seeds with an Open Source Seed (OSS) License. Working Paper. AGRECOL. Guggenhausen [web page]. Available at: http://www.opensourceseeds.org/ en/licence. Accessed on May 31, 2017.

La Via Campesina. 2012. The Bali Seed Declaration. Views, Experiences and Best Practices on the Implementation of Farmers' Rights Submitted by Contracting Parties and Relevant Organizations. The International Treaty on Plant Genetic Resources for Food and Agriculture, FAO, Rome. Available at: http://www.fao.org/3/a-bb912e.pdf. Accessed on May 31, 2017.

La Via Campesina. 2016. Industry Benefits but does not Pay its Dues. Patents are an Assault on 
Genetic Resources [web page]. Available at: https://viacampesina.org/en/industry-benefitsbut-does-not-pay-its-dues-patents-are-an-assaulton-genetic-resources/. Accessed on June 12, 2018.

Missouri Botanical Garden. 2010. Missouri Botanical Garden DNA Bank Material Transfer Agreement. Available at: http://

www.missouribotanicalgarden.org/plant-science/ plant-science/william-l-brown-center/wlbcresources/wlbc-databases/dna-bank.aspx. Accessed on May 31, 2017.

Nazarea, V. D., R. E. Rhoades, and J. AndrewsSwann. 2013. Seeds of Resistance, Seeds of Hope: Place and Agency in the Conservation of Biodiversity. University of Arizona Press, Tucson, AZ.

Nabhan, G. P. 2016. Conservation You Can Taste: Heirloom Seed and Heritage Breed Recovery in North America. In Ethnobiology for the Future: Linking Cultural and Ecological Diversity, edited by G. P. Nabhan, pp. 184-196. University of Arizona Press, Tucson, AZ.

Native Seeds/SEARCH. 2015. Safe Seeds, Organic Practices, GMOs [web page]. Available at: https:// shop.nativeseeds.org/pages/safe-seeds-organicpractices-gmos. Accessed on May 31, 2017.

Native Seeds/SEARCH. 2015a. Accession sheet/ Accession intake form. Native Seeds/SEARCH, Tucson, AZ.
Oguamanam, C. 2011. Genetic Resources \& Access and Benefit Sharing: Politics, Prospects and Opportunities for Canada after Nagoya. Journal of Environmental Law and Practice 22:87-124.

Posey, D. A. 1990. Intellectual Property Rights: What is the position of Ethnobiology? Journal of Ethnobiology 10:93-98.

Scott, K., and O. Receveur.1995. Ethics for Working with Communities of Indigenous Peoples. Canadian Journal of Physiology and Pharmacology 73:751 -753. DOI:10.1139/y95-099.

Swiderska K., A. Argumedo, Y. Song, J. Li, R. Pant, H. Herrera, D. Mutta, P. Munyi, and S. Vedavathy. 2009. Protecting Community Rights over Traditional Knowledge: Implications of Customary Laws and Practices [web page]. Key Findings and Recommendations 2005-2009. Report number 1459IIED. International Institute for Environment and Development, London. Available at: http://pubs.iied.org/14591IIED/. Accessed on June 12, 2018.

Wilder, B. T., C. O’Meara, L. Monti, and G. P. Nabhan. 2016. Ethnoscience, the "Oldest Science". In Ethnobiology for the Future: Linking Cultural and Ecological Diversity, edited by G. P. Nabhan, pp. 184-196. University of Arizona Press, Tucson, AZ. 